\title{
Black Women's Groups, Life Narratives, and the Construction of the Self in Late Twentieth- Century Britain
}

\author{
Jessica White (1) \\ Department of History, University of Manchester, Manchester, UK \\ Email: Jessica.white@manchester.ac.uk
}

\begin{abstract}
Black British women's centres and groups evolved out of black women's combined exclusion from male-dominated anti-racist activism and the resurgent feminist movement of the late 1960s. And yet, despite their stable presence in many of Britain's inner cities, black women's centres and groups, and the lives of the women who forged them, have evaded historical interrogation. This article explores how black women's centres provided women with the space and time to nurture their personal experiences of sexism and racism, achieve a sense of self-sufficiency, and celebrate their heritage, which placed every member on a path towards self-discovery. This centring of the black female self was not, as black male activists believed, set on undermining the Black liberation movement, but was considered as a vital tool in the overarching mission to defeat white global supremacy. Drawing on a collection of oral history interviews, this article explores how black female activists constructed a sense of self that turned away from the homogenizing white gaze of post-war Britain. Teasing out the complexities around black female activism, selfhood, and memory, this article contributes substantially to the growing body of literature on late twentieth-century black British history.
\end{abstract}

In 1975, three sisters, Ada Phillips, Coca Clarke, and Kathleen Locke, helped found the Manchester Black Women's Co-operative (MBWC) in Moss Side, just south of the city's centre. Their project retrained unsupported and unqualified black mothers in the office skills needed to re-enter the workplace in Manchester. ${ }^{1}$ The MBWC was housed at the Moss Side People's Centre, which

\footnotetext{
${ }^{1}$ Throughout, the term 'black', unless otherwise stated, is used as an insufficient descriptor that considers women of both African and Caribbean descent and their shared experienced as women racialized as black in Britain; it differs from the contemporary use of the term 'Black', which was used as a collective term to signify the shared experience of people of both black and South African descent. Interview with Coca Clarke, 1982, Ahmed Iqbal Ullah Race Relations Resource Centre,

(C) The Author(s), 2021. Published by Cambridge University Press. This is an Open Access article, distributed under the terms of the Creative Commons Attribution licence (https://creativecommons.org/licenses/by/4.0/), which permits unrestricted re-use, distribution, and reproduction in any medium, provided the original work is properly cited.
} 
they shared with the George Jackson Trust, a charity whose aim was to house homeless black residents in Moss Side. The trust had received substantial government funding in the 1970s, and, under the leadership of Ron Phillips, channelled this funding into the MBWC. After four years, Phillips, who was managing the funds, began to interfere in the MBWC's day-to-day management and it soon emerged that he was redirecting money from the co-operative funds into other local initiatives. On 26 October 1979, when Phillips tried to relocate the women's group, the founding members of the co-operative staged an occupation in their room of the centre. Subsequently, after a protest lasting ten days, on 1 January 1980, the MBWC reformed as the Abasindi Co-operative, completely autonomous from the trust, aimed at improving the lives of local women in the area by providing a place 'for the exchange of information and personal development'. ${ }^{2}$ Abasindi became one of several black women's centres that had opened across Britain during the 1970s, providing both a political base and a social hub for black women in cities such as London, Liverpool, and Birmingham. ${ }^{3}$ However, despite their stable presence in many of Britain's inner cities, black women's centres and groups, and the lives of the women who forged them, have evaded historical interrogation.

Black British women's centres and groups evolved out of the exclusion of black women from male-dominated anti-racist activism and the resurgent feminist movement of the late 1960s. ${ }^{4}$ By the 1980s, black and South Asian British female academics such as Hazel Carby, Claudette Williams, and Chandra Mohanty were articulating their experiences of racialized and gendered exclusion from both feminist and Black liberation struggles. ${ }^{5}$ Black women's centres and groups were thus set up to offer a variety of services designed for black women, including dancing and drumming workshops, welfare advice, craft sessions, and courses in black women's studies. In 1978, the Organisation of Women of African and Asian Descent (OWAAD) was formed in Brixton, acting as a central hub for these groups in England to communicate with and be kept informed of national campaigns that were relevant to them.

Manchester (AIU), Roots Oral History collection. However, 'Black' is retained in titles of publications where the authors chose to use the capital.

2 'Abasindi Co-operative booklet', n.d., AIU, Elouise Edwards collection (EE), GB3228.5/5, p. 3.

${ }^{3}$ Diane Watt, 'Silent warriors: the women of the Abasindi Co-operative', n.d., AIU, 'Manchester's black community', GB3228.8/14, p. 4. Following the incident, Ron and Ada separated and Ron soon returned to his native country, Guyana: Hal Austin, 'Obituary: Ron Phillips', Independent, 9 November 1998, http://www.independent.co.uk/arts-entertainment/obituary-ron-phillips1183773.html.

${ }^{4}$ Natalie Thomlinson, Race, ethnicity and the women's movement in England, 1968-1993 (London, 2016), pp. 65-102.

${ }^{5}$ Hazel Carby, 'White woman listen! Black feminism and the boundaries of sisterhood', in Centre for Contemporary Cultural Studies, ed., The empire strikes back: race and racism in 70s Britain (London, 1982), pp. 212-35; Claudette Williams, 'We are a natural part of many different struggles: black women organizing', in Winston James and Clive Harris, eds., Inside Babylon: the Caribbean diaspora in Britain (London, 1993), pp. 153-63; Chandra Talpade Mohanty, 'Under Western eyes: feminist scholarship and colonial discourses', Feminist Review, 30 (1988), pp. 61-88. See also Beverley Bryan, Stella Dadzie, and Suzanne Scafe, The heart of the race: Black women's lives in Britain (London, 1985). 
While scholars have paid attention to the history of OWAAD, the development of local black women's groups has hardly been addressed and black women's centres least of all. ${ }^{6}$ However, black women's groups in Manchester differed from OWAAD in that they largely responded to challenges generated by the local area. For instance, they focused on redressing the unemployment that came with deindustrialization, as Britain's shift towards a service-based economy resulted in mass unemployment in Moss Side. ${ }^{7}$ Moreover, the increase in heavy-handed policing in the area, which led to the outbreak of conflict between local residents and the police in 1981, provided the impetus for black women's groups to support victims of police violence and get involved in anti-police defence campaigns. ${ }^{8}$ Thus, viewing black female activism from the regional perspective identifies the central importance of the 'local', not merely to black female organizing, but in understanding black British history more broadly.

To unpack this history, this article examines the personal experiences of black women who founded and attended black women's centres and groups in the 1970s and 1980s. It demonstrates the ways in which these organizations allowed black women to fashion a sense of self in a period when journalists, social researchers, and politicians all constructed a homogenizing narrative of black womanhood as, among other things, over-fecund, isolated, and welfare-dependent. ${ }^{9}$ Black women's centres provided women with the space and time to nurture their personal experiences of sexism and racism, achieve a sense of self-sufficiency, and celebrate their heritage, which placed every member on a path towards self-discovery. This centring of the black female self was not, as some black and South Asian male activists believed, set on undermining the anti-racist movement, but was considered as a vital tool in the overarching mission to defeat global white supremacy. ${ }^{10}$ This article will demonstrate that, while these groups allowed women to unite in their shared experience as black women in Britain, they also fostered a social environment where they could construct a sense of self that was founded on the histories, ancestries, politics, and culture of the global African diaspora. Examining black British women's activism from the perspective of selfhood, the article inserts 'the personal' into the political history of late twentieth-century black British

\footnotetext{
${ }^{6}$ Thomlinson, Race, pp. 89-102. See also Julia Sudbury, 'Other kinds of dreams': Black women's organisations and the politics of transformation (London, 1998).

${ }^{7}$ For deindustrialization, see Jim Tomlinson, 'De-industrialization not decline: a new metanarrative for post-war British history', Twentieth Century British History, 27 (2016), pp. 76-99.

${ }^{8}$ For more on the Moss Side Riots, see Shirin Hirsch and David Swanson, 'Photojournalism and the Moss Side riots of 1981: narrowly selective transparency', History Workshop Journal, 89 (2020), pp. 221-45.

${ }^{9}$ Wendy Webster, Imagining home: gender, 'race' and national identity, 1945-64 (London, 1998); Helen McCarthy, 'Pearl Jephcott and the politics of gender, class and race in post-war Britain', Women's History Review, 28 (2019), pp. 779-93; Sally Tomlinson, 'Enoch Powell, empires, immigrants and education', Race, Ethnicity and Education, 21 (2018), pp. 1-14.

${ }^{10}$ For male scepticism of female-centred activism in the Black liberation movement, see A. Sivanandan, Communities of resistance: writings on Black struggles for socialism (London, 1990), p. 39.
} 
activism, which has predominantly been skewed towards charting intellectual origins and protests methods, and their impact on legislation. ${ }^{11}$

The article analyses how black women's centres and groups provided black women with a means to articulate individual and authentic selves in the late twentieth century. As such, it moves beyond the Windrush narratives of settlement, labour, and citizenship that have hitherto preoccupied historians of black British womanhood. ${ }^{12}$ While the scholarship on the Windrush generation has necessarily amplified the marginalized voices of black female migrants, there has been little examination of the lives of African Caribbean women from the 1970s, particularly those outside London. However, as Kieran Connell and Rob Waters have recently demonstrated, the latter half of the twentieth century can be characterized by the development of new political and social infrastructures, based around anti-racist activism, religion, and even sport, that bolstered the development of a distinct black British culture and identity. ${ }^{13}$ To date, black women's centres, and the lives of those who used them, have not been included within these recent histories of black Britain. By examining the history of such organizations, this article makes crucial headway into developing a history of what it meant to be a black British woman in the late twentieth century, once the dust had settled at Tilbury.

To explore these themes, the article analyses publications, grassroots magazines, and marketing materials issued by black women's groups in Manchester and London. It also draws from a collection of transcribed life history interviews with black female activists that took place in 2008 and 2009, now held at Lambeth Archives. The interviews were not conducted by the author, but formed part of the 'Do you remember Olive Morris?' (DYROM) project, which was set up by the artist and activist Ana Laura Lopez De La Torre to resurrect the life story of the prominent black female activist Olive Morris. ${ }^{14}$ Morris, born in 1952, had moved from Jamaica to Brixton at the age of nine and became part of the Black Panther Youth League and the squatters' rights movement in the 1970s. She was also instrumental in setting up the Brixton Black Women's Group in 1973, and later OWAAD in 1978. Unfortunately, after a diagnosis of leukaemia, Morris died in July 1979 at the age of twentyseven. The interviews used in this article are with those women who knew

\footnotetext{
${ }^{11}$ For intellectual origins, see Rob Waters, Thinking Black: Britain, 1964-1985 (Berkeley, CA, 2018); Kieran Connell, Black Handsworth: race in 1980s Britain (Berkeley, CA, 2019), ch. 1. For protest, see Michael Higgs, 'From the street to the state: making anti-fascism anti-racist in 1970s Britain', Race and Class, 58 (2016), pp. 66-84; Simon Peplow, Race and riots in Thatcher's Britain (Manchester, 2019); Daniel Renshaw, 'The violent frontline: space, ethnicity and confronting the state in Edwardian Spitalfields and 1980s Brixton', Contemporary British History, 32 (2018), pp. 231-52. For the impact on legislation, see Ron Ramdin, The making of the Black working class in Britain (Aldershot, 1987), ch. 7.

12 Webster, Imagining home; Mary Chamberlain, 'The global self: narratives of Caribbean migrant women', in Tess Coslett, Celia Lury, and Penny Summerfield, eds., Feminism and autobiography: texts, theories, methods (London, 2000), pp. 154-66. See also Kennetta Hammond Perry, London is the place for me: Black Britons, citizenship, and the politics of race (New York, NY, 2016).

${ }^{13}$ Connell, Black Handsworth; Waters, Thinking Black.

${ }^{14}$ Tanisha C. Ford, 'Finding Olive Morris in the archive', Black Scholar, 46 (2016), pp. 5-18, at p. 7.
} 
Morris while she was a mature undergraduate student in Manchester between 1975 and 1978, where she quickly embedded herself in the local black activist network in Moss Side. It is through these oral history interviews that there is now a wealth of material on black women's local activism in Manchester.

Oral history is one of the most effective means for recovering the history of female activism, which has evaded traditional forms of documentation, as Margaretta Jolly's most recent oral history of the women's liberation movement has demonstrated. ${ }^{15}$ While such an analysis diverges from the DYROM project's intended purpose of documenting the history of Morris, there are numerous benefits to this secondary analysis of oral history interviews, not least because it allows the documenting of the uncharted personal stories of black women in Britain. ${ }^{16}$ Granted, there are several ethical challenges raised by this analysis of oral history data. For instance, black women's groups and centres were autonomous safe spaces that sought solace and sanctity from the homogenizing white gaze of post-war Britain, and a secondary analysis could intrude upon these spaces and potentially reify this gaze. However, this article demonstrates that the women who contributed to the DYROM project were aware that they were part of a unique generation of black female activists, and were explicit in making sure that their own history, as well as Morris's, was documented. One must therefore perform a delicate balancing act between respecting the closed nature of black women's groups and recovering the history of regional black female activism. Thus, the article seeks to identify the interviews' value in contributing to the history of black women's organizing in Britain, and particularly in the north, all the while being careful not to speak for, or over, the women involved in the project.

One of the challenges posed by the DYROM collection is that, by being encouraged to narrate their life stories thirty years after their interaction with the revered Morris, these women may have been prompted to overstate the impact that the activist had on their lives. However, oral history has never been geared towards merely gathering the 'facts'. As Alessandro Portelli writes of this form of history, rather than dismiss 'errors, myths, interventions, lies ... we investigate their meaning and what they tell us about the narrator's world'. ${ }^{17}$ Thus the final section of the article focuses on how black women constructed a sense of self in the oral history interview process. It builds on oral history theory developed by Portelli, Penny Summerfield, Lynn Abrams, and others to demonstrate that, through the interview process, the women had the unique opportunity to construct personal identities in which their status as female activists came to the fore ${ }^{18}$ It also draws on Abrams's concept of

\footnotetext{
${ }^{15}$ Margaretta Jolly, Sisterhood and after: an oral history of the UK women's liberation movement, 1968present (Oxford, 2019); Joanna Bornat and Hanna Diamond, 'Women's history and oral history: developments and debates', Women's History Review, 16 (2007), pp. 19-39.

${ }^{16}$ Joanna Bornat, 'A second take: revisiting interviews with a different purpose', Oral History, 31 (2003), pp. 47-53, at p. 49; April Gallwey, 'The rewards of using archived oral histories in research: the case of the Millennium Memory Bank', Oral History, 41 (2013), pp. 37-50.

${ }^{17}$ Alessandro Portelli, 'Living voices: the oral history interview as dialogue and experience', Oral History Review, 45 (2018), pp. 239-48, at p. 247.

${ }^{18}$ Penny Summerfield, Histories of the self: personal narratives and historical practice (Abingdon, 2019), p. 128. See also Lynn Abrams, Oral history theory (Abingdon, 2010); Luisa Passerini, Fascism
} 
'feminography', a form of life story in which being a woman is central to the personal narrative, rather than other traditional frameworks such as motherhood or marriage. ${ }^{19}$ Moreover, these narratives diverged from traditional Western theories of the self, which stipulate that the self is unique, and the construction of the self is an individual act. ${ }^{20}$ Instead, the article builds on the work of Mary Chamberlain and other scholars, whose analyses of non-Western women's life stories demonstrate how their stories often incorporated the memories of their families, reflected a shared consciousness with their grandmothers and mothers, and articulated selves formed of the different lineages of their female kin. ${ }^{21}$ Similarly, it argues that, while these women did produce individual and distinctive modes of self, they also built their sense of self around their political engagement with, and on behalf of, other women.

This article, then, has two objectives: first, to sketch out a personal history of the intellectual and social contours of black women's centres in the 1970s and 1980s; and second, to reveal how, through the oral history interview, black female activists construct a sense of self that turns away from the homogenizing white gaze of post-war Britain. To begin this analysis, the article charts the ideological origins of black women's groups, outlining the values of collective self-sufficiency, personal autonomy, and self-actualization that underpinned women's centres and their outreach work in the community. The second section explores the services and opportunities within black women's centres that allowed black women to fashion their individual identities, whether through celebrating and exploring their African heritage, or through entering interpersonal conflict. The third and final section considers what the individual memories of black women's groups reveal about the construction of the black female self in post-war Britain. Teasing out the complexities around black female activism, selfhood, and memory, the article contributes substantially to the growing body of literature on late twentiethcentury black British history.

I

While drawing on the experiences of black female activists across England, this article focuses largely on those who lived in Moss Side in the 1970s and 1980s. An inner-city area situated two miles south of Manchester's city centre, Moss Side was once an industrial neighbourhood that became a migrant gateway to a generation of Caribbean workers, following their migration to Britain from the

in popular memory: the cultural experience of the Turin working class (Cambridge, 1987); Alessandro Portelli, The death of Luigi Trastulli and other stories: form and meaning in oral history (Albany, NY, 1991).

${ }^{19}$ Lynn Abrams, 'Heroes of their own life stories: narrating the female self in the feminist age', Cultural and Social History, 16 (2019), pp. 205-24.

${ }^{20}$ Abrams, Oral history theory, p. 36.

${ }^{21}$ Mary Chamberlain, 'Family and identity: Barbadian migrants to Britain', in Mary Chamberlain, ed., Caribbean migration: globalized identities (London, 1998), pp. 152-66; Sue Anderson, Jaimee Hamilton, and Lorina L. Barker, 'Yarning up oral history: an indigenous feminist analysis', in Katrina Srigley, Stacey Zembrzycki, and Franca Iacovetta, eds., Beyond women's words: feminisms and the practices of oral history in the twenty-first century (Abingdon, 2018), pp. 170-83. 
Commonwealth after the Second World War. ${ }^{22}$ From the 1950s, it was home to a stable and politically conscious black population, who had established a variety of community organizations to meet the practical needs of its African Caribbean residents, dealing with issues ranging from housing and healthcare to police harassment and racism in school. By the 1970s, male community workers governed most of these groups, and black women's own involvement in community work was often discouraged. In 1977, two local residents, Kathleen Locke and Elouise Edwards, established the Black Women's Mutual Aid (BWMA) to address the educational needs of children in Moss Side. In her oral history testimony, Edwards, who was born in Guyana in 1932 and migrated to Britain in the 1950s in her late twenties, remembered how the group would meet at the local West Indian social club every Sunday, where many of the members' husbands would also be socializing. However, meeting in these mixed-sex environments led to the organization's demise. Recounting the early years of the group, Edwards reflected that the husbands 'used to give their wives hell, when their wives went home you know ... that was one of the reasons why it [the BWMA] just collapsed, women stopped coming because they were having a hard time.. ${ }^{23}$

While this experience of male resistance dissuaded some women from getting involved in local activism, it informed the central values of collective female self-determination that underscored women's centres of the later 1970s. For Moss Side's Abasindi, the black women's co-operative that had grown out of the male dogmatism of the local leader Ron Philips, collective female autonomy was a central value to its founding ideology. In a booklet published by Abasindi, the founders wrote that it was agreed that the Co-Operative should show itself to be clearly autonomous and selfdetermining' and 'that Black women need to organize projects staffed and controlled by women'. ${ }^{24}$ As Tracey Fisher has demonstrated in her study of black women's centres in Southwark, black women felt unheard in mixed-sex black grassroots organizations in the 1970s and 1980s, and this desire for autonomy from male interference was also articulated in the ways that Abasindi members defined the organization's name. ${ }^{25}$ One of the co-operative members, Lindiwe Tsele, defined Abasindi as 'a Zulu name meaning those who have escaped, because we didn't all realise the powerlessness of black men, because they wanted to be in charge of us and we were saying this is a women's group'. ${ }^{26}$ Similarly, in their account of the co-operative, the former members Diana Watt and Adele Jones stated that Abasindi was Zulu for 'survivors', meaning the 'strength, resilience and competence of black

\footnotetext{
${ }^{22}$ Laurence Brown and Niall Cunningham, 'The inner geographies of a migrant gateway: mapping the built environment and the dynamics of Caribbean mobility in Manchester, 1951-2011', Social Science History, 40 (2016), pp. 93-120, at pp. 100-3.

${ }^{23}$ Interview with Elouise Edwards, 2009, Lambeth Archives (LA), 'Do you remember Olive Morris?' oral history project (DYROM).

24 'Abasindi Co-operative booklet', p. 4.

${ }^{25}$ Tracy Fisher, 'Black women, politics, nationalism and community in London', Small Axe, 11 (2002), pp. 133-50, at p. 142.

${ }^{26}$ Interview with Lindiwe Tsele, 2009, LA, DYROM.
} 
women'. ${ }^{27}$ Both definitions highlighted the female-centred, independent nature of the group. Indeed, this collective autonomy also trickled down to encouraging individual autonomy among black women. In London, the Tottenham-based United Black Women's Action Group, who later set up and ran the Haringey Black Women's Centre from 1983 until its closure in 1984, stressed that their central aim was to 'assist Black women to help themselves'. ${ }^{28}$ The need for women to be both collectively and individually selfsufficient was at the root of black women's female-centred activism.

For the members of Abasindi, autonomy was not simply about distancing themselves from the dogmatism of black men within activist groups. In Manchester, mainstream feminist groups failed to address the poverty and racism experienced by the African Caribbean community in Moss Side, with activism largely circulating within and around the University of Manchester. This disconnect was illustrated in the bold ethnocentricity of white-led feminist publications in the city. The lack of intersectional awareness was reflected in an article on South Asian women from the Manchester Women's Paper, a local community paper that ran from 1976 to 1981 :

Manchester's Asian women live together in certain areas and the women lead very restricted lives ... Islam is a total way of life. It governs every part of a woman's life. She only exists as a member of a family; she is not seen as an individual acting of her own accord. ${ }^{29}$

Not only did the anonymous author elide the differences between religion and nationality in the piece, but the article also assumed that an Asian woman's independence was diminished because of her social position in the family. Remarkably, the Manchester Women's Paper was printed in the centre of Moss Side, where one-third of the population was of African descent, and yet the authors displayed no awareness of the problematic nature of their representation. The paper also displayed its disconnect with the experiences of ethnic minorities in its celebratory coverage of a local Reclaim the Night (RTN) event in 1977. Demonstrating the authors' lack of awareness of issues related to police harassment of black communities, the publication lauded the event, in which police officers were deployed to protect female protestors in a march against rape. ${ }^{30}$ As Natalie Thomlinson has also noted, white feminists in Leeds held police-assisted RTN events through the so-called 'black area' of Chapeltown, displaying a tone-deaf attitude to

\footnotetext{
${ }^{27}$ Diana Watt and Adele D. Jones, Catching hell and doing well: Black women in the UK - the Abasindi Cooperative (London, 2015), p. 1.

${ }^{28}$ United Black Women's Action Group flyer, n.d., Black Cultural Archives, Brixton, London (BCA), Dadzie collection (DAD), DADZIE/1/1/30/2. In 1984, a dispute broke out between members over pay; there are no records after this date pertaining to the centre's activities.

29 'Asian women', Manchester Women's Paper, 10 (1977), Feminist Archive North, Leeds (FAN), Manchester Women's Paper (MWP), FAN/PER/659, p. 11.

30 'A woman's place is ... everywhere', Manchester Women's Paper, 11 (1977), FAN, MWP, FAN/PER/ 659, p. 14.
} 
issues of police racism. ${ }^{31}$ Indeed, in the Manchester Women's Paper's lifetime, there was no coverage of police racism or any matters related to Manchester's black women.

Overall, the members of Abasindi could not associate with local feminism. Reflecting on her involvement in women-centred activism, Elouise Edwards noted that 'the white women's groups that were around ... we didn't feel that we wanted to be part of that because our problems were different, you know, because we had the issue of racism ... which of course the white ones [groups] didn't have'. ${ }^{32}$ Instead, black female activists in Moss Side adopted their own political framework that distanced itself from local white feminism. In their biography of the Abasindi Co-operative, Watt and Jones wrote that, although 'Abasindi espoused feminist values, we did not always describe ourselves as a feminist organisation'; instead, the founders claimed that their 'feminism was pragmatic and socially meaningful to our realities'. ${ }^{33}$ Inspired partially by Pan-African philosophy, Abasindi built a political outlook that centred on the experience of black women in the global black diaspora, and celebrated early Pan-African black female activists like Amy Ashwood Garvey and Amy Jacques Garvey. ${ }^{34}$ The members took inspiration from the fact that both women attended the 1945 Pan-African Congress, which took place in Manchester, and the co-operative even helped campaign for a blue plaque commemorating the event. ${ }^{35}$ Other black women who campaigned in Britain, such as the Trinidadian-born Communist exile Claudia Jones, were also a source of inspiration. Jones set up the West Indian Gazette, the first popular newspaper in Britain dedicated to covering Afro-Asian news, and organized the first Caribbean festival in 1959, the origin of the Notting Hill Carnival. She also helped develop the theory of 'triple oppression', arguing in her work that black women were the victims of racism, classism, and sexism, and that freeing black women from this exploitation would lead to freedom for all who were oppressed. ${ }^{36}$ While Abasindi's literature did not explicitly refer to Jones's writing, it did engage with the related idea of womanism, the theory developed by the African American Alice Walker in the 1970s that encompasses black women's unique struggles with racism and sexism. ${ }^{37}$ In many ways, Abasindi connected with some of the intellectual roots of 'intersectionality', a term coined by Kimberlé Crenshaw in the late 1980s to theorize

\footnotetext{
${ }^{31}$ Thomlinson, Race, p. 169. See also Finn Mackay, 'Mapping the routes: an exploration of charges of racism made against the 1970s UK Reclaim the Night marches', Women's Studies International Forum, 44 (2014), pp. 46-54. For contemporary criticisms from black feminists, see Williams, 'We are a natural part', p. 162.

${ }^{32}$ Interview with Edwards, LA, DYROM.

${ }^{33}$ Watt and Jones, Catching hell, p. 130.

${ }^{34}$ Watt, 'Silent warriors', p. 3.

${ }^{35}$ Watt and Jones, Catching hell, p. 28.

${ }^{36}$ Claudia Jones, 'An end to the neglect of the problems of the Negro woman!', Political Affairs (1949), https://palmm.digital.flvc.org/islandora/object/ucf\%3A4865.

${ }^{37}$ Watt and Jones, Catching hell, p. 34. See Patricia Hill Collins, 'What's in a name? Womanism, black feminism, and beyond', in Layli Phillips, ed., The womanist reader (New York, NY, 2006), pp. 57-68.
} 
black women's intersecting experiences of sexual and racial discrimination on account of being both black and female. ${ }^{38}$ This engagement with black female intellectual thought allowed the co-operative to develop its own womancentred philosophy that was both national and global in its inspiration.

While they adopted a transnational political outlook, black women's groups tended to work towards addressing immediate local issues. Moss Side's black women were instrumental in campaigning against racism in the local schools, in which black school children were not only obtaining lower grades than white pupils, but were also targeted by the police. ${ }^{39}$ As noted above, Elouise Edwards helped in setting up the educational action group the BWMA, and Abasindi itself ran a supplementary school for local schoolchildren on Saturdays. ${ }^{40}$ Moreover, the group responded to the effects of deindustrialization. By the 1970s, the selection of manufacturing jobs available to migrant workers in Manchester had fallen into decline. Moss Side was particularly badly hit. In the 1981 census, 36.4 per cent of men in Moss Side were unemployed, compared to 14.0 per cent in Greater Manchester, and 16 per cent of households were headed by unskilled workers, compared to 6 per cent in the county. The effects of deindustrialization played an important role in dictating the shape of black female community activism. For instance, creeping unemployment among young residents pushed Abasindi to set up skills-training workshops in secretarial skills for local women. Moreover, the number of unemployed young black residents in Moss Side invited scrutiny and harassment from local police, leading to the Moss Side riots in 1981. Abasindi was actively involved in helping residents during the disturbances, turning itself into a hospital for people who were injured. ${ }^{41}$

As they responded to the day-to-day issues of the post-industrial north, members of Abasindi were also involved in national campaigns, including the protests at Greenham Common and the miners' strikes. ${ }^{42}$ Moreover, some members, such as Lindiwe Tslele, were involved in African liberation protests, like those against South African Apartheid. ${ }^{43}$ Abasindi's position paper from 1979 reflected a sense of solidarity with black people across the globe:

\footnotetext{
${ }^{38}$ Kimberlé Crenshaw, 'Demarginalizing the intersection of race and sex: a black feminist critique of antidiscrimination doctrine, feminist theory and antiracist politics', University of Chicago Legal Forum, 140 (1989), pp. 139-67.

39 'Press statement: schools join police in terrorising school students: no bogus charges against Stephen Locke', c. 1980, George Padmore Institute, London (GPI), Black Parents Movement (BPM), $\mathrm{BPM} / 3 / 2 / 3 / 9$.

${ }^{40}$ Watt and Jones, Catching hell, pp. 109-18. For black supplementary schools, see Kehinde Andrews, Resisting racism: race, inequality, and the Black supplementary school movement (London, 2013); Jessica Gerrard, 'Self help and protest: the emergence of Black supplementary schooling in England', Race, Ethnicity and Education, 16 (2013), pp. 32-58; Heidi Safia Mirza and Diane Reay, 'Spaces and places of Black educational desire: rethinking Black supplementary schools as a new social movement', Sociology, 34 (2000), pp. 521-44.

${ }^{41}$ Interview with Edwards, LA, DYROM.

${ }^{42}$ Watt and Jones, Catching hell, p. 26.

${ }^{43}$ Interview with Tsele, LA, DYROM.
} 
We should realise that as women we have taken part in the struggles, and if this means organising a training scheme which would benefit our sisters dying in bushes in Africa and the Caribbean, we will do it. We are part of the evolution process of the liberation of the Black race and the respect of a nation lies in its women. ${ }^{44}$

Thus, by situating their local activism within a globalized, and gendered, discourse of racial justice, the founders of black women's centres provided a rationale for the necessity of local, female-centred spaces in the journey towards overcoming the racism experienced by all (women) in the black diaspora.

Moss Side's black women's groups and centres fostered a sense of 'intersectional' awareness among their members. These groups were spaces that allowed black women to construct their unique form of political outlook, which addressed their realities and concerns without fear of reproach from mainstream feminism and anti-racist activism. The members established their own distinctive framework of feminism that contested the political grammar of Western feminist theorization, and, in doing so, the groups fostered the emotional space that enabled members to centre their collective lived experience as black women. These groups responded to the aftermath of deindustrialization, but imbued their local activism with global perspectives of the black female experience, which, as the next two sections will demonstrate, played a fundamental role in the construction of the black female self in late twentieth-century Britain.

\section{II}

Black women's groups focused their aims on developing individual female selfsufficiency, which would provide black women with the tools to defeat racism in their local area and in Britain. To achieve this sense of individual autonomy, members had to 'reclaim the self', reaching a point of self-acceptance and understanding that gave women the armour that could resist the debilitating effects of societal racism and objectifying images of black womanhood. ${ }^{45}$ The first stage taken by black women's centres to get black women to reconnect with their sense of self was to engage them with the politics and culture of the black diaspora. Despite most of its members being of Caribbean heritage, Abasindi centred 'Africanness' within its activities and environment. The founders felt that, by centring the 'African self', the co-operative would create a collective identity among its members of both African and Caribbean descent, while also providing individual members "with the space to both "recover" and "discover" their African identity, which had for centuries been stigmatized in the colonial West. ${ }^{46}$ The co-operative connected members to their African heritage through hair-braiding, dressmaking, and renaming

\footnotetext{
${ }^{44}$ Position paper, part one, 26 Oct. 1979, GPI, BPM, BPM/3/2/3.

${ }^{45}$ Watt, 'Silent warriors', p. 9.

${ }^{46}$ Watt and Jones, Catching hell, p. 41.
} 
ceremonies, which enabled women to rename themselves in African languages such as Yoruba, Zulu, and Xhosa. One woman remembered that 'as a Diasporan African born and raised in Moss Side ... the name Olajumoke Sankofa resonates with the heartbeat of Africa, reconnecting me to the authentic essence of who I am ${ }^{, 47}$ Renaming was thus not only a way for Sankofa to reconnect with her African heritage, but also a way for her to reconnect and realize her sense of self as an African woman living in Britain. As Abasindi's African-centred praxis demonstrates, the path towards self-actualization in black women's groups spotlighted, rather than marginalized, their ethnic identities.

Newsletters provided another device that centred black women's identities, serving as a cultural outlet for black female self-expression that resisted and challenged negative stereotypes that members encountered about themselves in the mainstream media. Following the large-scale migration from the Caribbean in the post-war decades, the depiction of black women as villainous and parasitical permeated popular political and cultural discourse. ${ }^{48}$ In his infamous 'Rivers of blood' speech in 1968, Enoch Powell ignited fears early on about black and South Asian mothers draining the country's healthcare resources. ${ }^{49}$ Meanwhile, within academia, lone black mothers were also the subject of extensive research and debate. In A troubled area (1964), the social researcher Pearl Jephcott described the racial divisions between the white and African Caribbean mothers of west London, portraying an isolated black motherhood tied to the home. ${ }^{50}$ While this representation of lone black motherhood was sympathetic, it was not constructed on black women's own terms. Reflecting on Black Sista, the newsletter established by the north London-based Camden Black Sisters, Lindiwe Tsele noted that the founders 'wanted to write about our lives ... the only time you find anything written about a black person is when they've done wrong ... if you are doing something good or just of interest ... it's not of interest'. ${ }^{51}$ In this way, newsletters nurtured the need for black women to re-establish their own voice in cultural representations of black British womanhood.

In their wish to provide a platform for black women's voices, newsletters such as OWAAD's mouthpiece FOWAAD invited members to submit feature articles and reviews on different aspects of global black diasporic culture, and the pieces submitted helped women in their process of self-discovery. For instance, in a book review for Sula, written by the African American Toni Morrison, the reviewer noted that, 'Morrison ... writes about our lives, the lives of our grandmothers, and daughters. She touches so close and looks so deep into our souls that it is as if she has simply written down our thoughts as they come into our mind. ${ }^{52}$ By charting her engagement with Morrison's work, the anonymous

\footnotetext{
${ }^{47}$ Ibid., p. 46.

${ }^{48}$ Sadiah Qureshi, 'Displaying Sara Baartman, the "Hottentot Venus"', History of Science, 42 (2004), pp. 233-57.

${ }^{49}$ Tomlinson, Race, p. 5.

${ }^{50}$ Pearl Jephcott, A troubled area: notes on Notting Hill (London, 1964). See also McCarthy, 'Pearl Jephcott', pp. 785-8.

${ }^{51}$ Interview with Tsele, LA, DYROM.

52 “'Sula” by Toni Morrison', FOWAAD, 1980, BCA, DAD, DADZIE/3/2/2, p. 14, emphasis in original.
} 
author came to a sense of self that was constituted by an understanding that her experiences were shared with women throughout the black diaspora. In her study of Caribbean women's migrant life stories, Chamberlain has demonstrated that Caribbean women's subjectivities were often told through allying themselves with black relatives and other black women. Their stories represent 'not the autonomy, but the collectivity, of the individual'. ${ }^{53}$ By the same token, articulating her identification with Morrison, and her broader sense of kinship with her female relatives, the review's author reinforced the way in which these newsletters allowed women to construct their sense of self through imagined female-centred relationships across geographical and temporal planes.

These grassroots magazines also invited women to share their personal experiences of navigating racism and microaggressions in Britain through different art forms. For instance, in a cartoon strip from FOWAAD, 'Sister Owanda' enters her public library asking for a book by Buchi Emecheti or Toni Morrison, to which the white librarian responds, 'I remember we did have one novel by a knee-grow writer ... that lovely story about those slaves ... er, what was it called again'. ${ }^{54}$ Similarly, in 1984, the Haringey Black Women's Centre newsletter, United We Stand, published a poem entitled 'My home', in which the author, Gwendalyn Goodman, narrated her personal experience of everyday racism:

Some asked me, "why leave your country

And come here?' 'Why don't you go back

To the jungle where you came from?'

'Go back to Africa.' I know who my

Ancestors are, more than I can say for

Some, like you for one, she pushed her

Toffee nose up into the air it tempted

Me to push my brolly up there ${ }^{55}$

While these forms of self-expression indicated that black women constructed their sense of self through their negative interactions with whiteness, these interactions did not define them. ${ }^{56}$ Instead, recounting these encounters created an opportunity to construct an assertive self that resisted and mocked this racism, while also allowing the women to make broader claims about personal belonging in Britain, demonstrated in the final lines of Goodman's poem: 'I must be strong seeing what I'm around, I'm strong because England is now my home.'

${ }^{53}$ Chamberlain, 'Global self', p. 159.

${ }^{54}$ FOWAAD, 1980, BCA, DAD, DADZIE/3/2/2, p. 14.

${ }^{55}$ Gwendalyn Goodman, 'My home', United We Stand, 2 (1984), BCA, DAD, DADZIE/1/5, pp. 10-11.

${ }^{56}$ For whiteness, see Alastair Bonnett, White identities: an historical and international introduction (Abingdon, 2014); Trina Jones and Kimberly Jade Norwood, 'Aggressive encounters and white fragility: deconstructing the trope of the angry black woman', Iowa Law Review, 102 (2016), pp. 2017-70; Jun Mian Chen, 'The contentious field of whiteness studies', Journal for Social Thought, 2 (2017), pp. 15-27; Bill Schwarz, 'Wild power: the aftershocks of decolonization and Black Power', in Daniel Geary, Camilla Schofield, and Jennifer Sutton, eds., Global white nationalism (Manchester, 2020), pp. 71-102. 
Other forms of cultural expression, such as hair-braiding sessions and drumming and dancing groups, allowed women to come together and forge personal bonds that outlived the existence of the groups. However, internal divisions also surfaced within women's groups, often centred on which campaign issues to support. Reflecting on her time as a member of the Camden Black Sisters in the 1980s, Lindiwe Tsele recalled an awkward moment in the group's history that had stuck in her memory. The group was divided over the subject of sex work, which came to a head during a meeting with Camden Council when the group's manager was found to support prostitution. The manager argued that 'we can't be seen to be all against them [sex workers]', articulating a form of universal female solidarity that did not sit comfortably with other members. As Judith Walkowitz has discussed, in the early 1980 s 'prostitution' became a central issue among women's rights campaigners, who raised concerns about the economic basis of sex work, as well as violent treatment of sex workers. ${ }^{57}$ However, Tsele and other members were concerned that by supporting sex workers they would be defined as such. In an emotive recollection of the event, Tsele described how she and other workers objected "because it came out like we were the prostitutes ... when we came out of that meeting we were not talking ... she was sat there and we were asking her what the fuck were you talking about [sic].$^{58}$ Given the context of the intense scrutiny of black women's sexual practices due to the disproportionate number of lone black mothers living in Britain's cities in the 1980s, it is not surprising that Tsele was concerned about appearing as a sex worker. ${ }^{59}$ By standing firm in their opposition to prostitution as a campaign issue, Tsele and her colleagues asserted their ownership over their personal identities in opposition to some of the universalizing tendencies of mainstream British feminism.

In Manchester, conflicts around prostitution rarely surfaced in the memories of activists, yet differences in political leanings could still pose an obstacle for creating solidarity. For instance, while Olive Morris had an important impact on the women she met in Moss Side, some members felt that she often overlooked local issues. When discussing the conflict between the MBWC and Ron Phillips over the mismanagement of company funds, Tsele noted that Morris 'was not in with those sorts of fights, those were just for us, grassroots', noting that she 'just used to come and help us with the intellectual bits, about how the system was working'..$^{60}$ Other women who knew Morris also drew attention to her structural approach to the social issues of the area. Maria Noble noted that Morris was 'an internationalist ... she was very outward looking ... so not at all parochial'. ${ }^{61}$ For some members, however, Morris's disregard for these 'parochial' issues served as a distraction from the

\footnotetext{
${ }^{57}$ Judith Walkowitz, 'Feminism and the politics of prostitution in King's Cross in the 1980s', Twentieth Century British History, 30 (2019), pp. 231-63.

${ }^{58}$ Interview with Tsele, LA, DYROM.

${ }^{59}$ Dervla Murphy, Tales from two cities: travel of another sort (London, 1987); Lozells Social Development Centre, Wednesday's children: a report on under-fives provision in Handsworth (Birmingham, 1975); Jephcott, Troubled area.

${ }^{60}$ Interview with Tsele, LA, DYROM.

${ }^{61}$ Interview with Maria Noble, 2009, LA, DYROM.
} 
problems relevant to Moss Side. 'They'd talk about the system ... the impact of capitalism', remembered Diana Watt, one of the founders of Abasindi, 'and that is okay, there's a place for that ... there's also, you know, that other bit that needs to be talked about ... what action can I take now in order to address issues that are impacting on the lives of my family? ${ }^{12}$ The issues that appeared to Morris as a reflection of the broader system of capitalism were, to others, the everyday problems tied to Moss Side. While these underlying differences never resulted in explicit antagonism, the very fact that these individual leanings existed, and that members acknowledged them, demonstrated how engaging in black female-centred activism provided women with an outlet for political self-examination and expression, regardless of what form it took.

Black women's centres thus opened avenues of self-expression in a variety of forms that were not always available to them outside these spaces. They encouraged women to look inwards through a variety of cultural infrastructures that provided their members with spaces to articulate a liberated self, which spoke not only to the shared diasporic experience of black womanhood, but also to their personal experiences of being a black woman in post-war Britain. While fractures and fissures took place, internal conflicts served black women with a tool to construct a sense of self by reflecting on their own political beliefs.

\section{III}

Thus far, this article has examined the memories of black women to sketch out a history of black women's groups and centres in the late 1970s and early 1980s. This final section builds on oral history theory to explore these memories further, to reveal how black women articulated their sense of self when asked to narrate their lives around their engagement in female-centred activism. Given that the women of the oral history project were all involved in contributing to the history of Olive Morris, it is unsurprising that the political activist played a prominent role in their life stories. One of these women was Wilma Deane. Deane was born in 1956, and first arrived in Manchester in 1974 to study law at the university. She had migrated at the age of five from Nevis in the Caribbean to Leeds, where she passed the eleven plus and went on to study in a 'traditional English grammar school'. ${ }^{63}$ At the beginning of her second year of university, after attending one of the infamous student nights at the West Indian Social Club in Moss Side in 1975, Deane met Morris. It was through her friendship with Morris that Deane also became more politically active, and the two young women joined the BWMA. Moreover, it was through Morris's contacts in London that Deane was able to get her first placement with a law firm in Brixton.

In her interview, Deane pivoted her transition from a shy law student to a political activist and social welfare lawyer around her first meeting with Morris. Reflecting on her years as a student, she noted:

\footnotetext{
${ }^{62}$ Interview with Diane Watt, 2009, LA, DYROM.

${ }^{63}$ Interview with Wilma Deane, 2009, LA, DYROM.
} 
I grew up in, in Leeds, in Yorkshire. I was very shy, coming to university was just an enormous thing, I'd had a very sheltered upbringing, and then I met Olive ... So I really sort of quite liked, tagging along sort of thing because she just seemed so fired up and, and so on, yeah. ${ }^{64}$

In her recollection, Deane's encounter with Morris served as an 'epiphanic moment', which Abrams describes as an incident or event that bridges a respondent's past self to their mature adult self. ${ }^{65}$ Deane was almost selfdeprecating about her timidity and somewhat embarrassed about her lack of political education prior to meeting Morris. To make sense of this past self, she employed her encounter with Morris to reconcile her past self as an ordinary student with the politically engaged woman she was at the time of narrating. Morris thus became a thread that was woven through Deane's multiple selves as she passed through her youth into adulthood.

Throughout her oral history interview, Deane continued to give Morris a central role in her life story. Asked whether Morris taught her to be more vocal about political issues, Deane remarked:

Yes ... I think so certainly ... I might have stayed as this, you know, little law student, but she sort of introduced me to sort of ways into the community, I mean, I might have got, got in there anyway ... what she did for me with working in that law firm was fantastic because it actually made me see yes, you could, I could do that and it gave me that experience as well, so it was, it was a fantastic experience, and she, you know, really put herself out for me, you know, was putting me up in her house, I mean we'd only, you know, met as students, and she was really helping me, so, so yeah, she did, and it was, it was an inspiration, and like talking about some of the [sic], cause I've spent all my career doing, you know, sort of social welfare law areas, and I think Olive's part of that. $^{66}$

Deane's reflexivity on her other life courses and her repeated use of selfdeprecating language demonstrated her sense of discomfort at hypothesizing about what might have happened had she not met Morris. As such, she was assertive in giving Morris a starring role in navigating her life story, whether that was providing Deane with the confidence to pursue law, housing her, or simply serving as a source of inspiration. However, rather than considering this as disempowering, Deane's concluding affirmative remark indicates that she reached some clarity about the positive and transformative impact that this interpersonal relationship had had on her sense of self.

Although enjoying a close friendship with Morris, Deane remembered feeling lacking in self-confidence in her presence because 'she was just so damn

\footnotetext{
${ }^{64}$ Ibid., emphasis added.

${ }^{65}$ Lynn Abrams, 'Liberating the female self: epiphanies, conflict and coherence in the life stories of post-war British women', Social History, 39 (2014), pp. 14-35, at p. 22.

${ }^{66}$ Interview with Deane, LA, DYROM.
} 
confident, she was energetic, things were happening'. Reflecting both admiration and envy, Deane remembered, 'I used to think, "Gosh, I wish I could speak up the way that she could." ${ }^{67}$ Diana Watt, a member of the MBWC, and later Abasindi, articulated similar memories. When asked to reflect on her first interaction with Olive, Watt commented that her vast political vernacular 'was a bit scary ... you kind of closed down rather that [sic] opened up. ${ }^{68}$ This introversion was not because of Morris, Watt recalled, but was due to her 'own sense of inadequacies'.

In these reflections, Morris's own confidence and eloquence encouraged both Deane and Watt to be introspective and examine themselves and their own identity later in life. However, it is likely that external cultural factors played a role in shaping both these memories. By the early 2000s, Morris had garnered a status among many activists as an articulate and outspoken young woman. For instance, photographs of the activist often show her at protests confronting police officers or with placards openly criticizing the state. The front cover of the Squatters' handbook also famously shows Morris scaling the front of a terraced house. ${ }^{69}$ Such visual representations have held up Morris's overall reputation as a fearless activist, and they may have fed into these women's recollections of her. Yet, rather than examining these feelings as false or a product of external factors, these memories demonstrated the way in which the interview process aided both women in actualizing deeper understanding of their past selves.

Unlike Deane, Watt positioned the MBWC as playing a central role in changing the course of her life story. She had trained as a secretary in the 1970s, and, after she met Kathleen Locke, she became involved in the MBWC and was a co-founder of Abasindi. Later in life, she returned to higher education and became an academic, writing a history of the Abasindi centre. In her life story, Watt had a distinct sense of her limited opportunities as a young woman in the 1970s, tied to the context of the deindustrialized north, where professional corridors were restricted to service sector clerical work for black women:

I left school - the main thing was to train as a secretary, I didn't had [sic] any aspirations beyond that because I saw that as the limit, 'cause my parents - again they are from the same period as Olive's parents, and my parents, their main advice was, 'we work in a factory, you work in an office', so I thought, 'I have achieved, you know, I work in an office.' When I became involved in the MBWC, then you hear the voice saying ... unlike the voice that you heard at school, which says, 'you can't', the voice that you were getting in the community was 'you have a responsibility to'. And it's through my involvement in community activity that influenced me to get back to education, yeah. ${ }^{70}$

\footnotetext{
${ }^{67}$ Ibid.

${ }^{68}$ Interview with Watt, LA, DYROM.

${ }^{69}$ Squatters' handbook (6th edn, London, 1979), LA, Olive Morris collection, IV 279/1/20/10.

${ }^{70}$ Interview with Watt, LA, DYROM.
} 
In this statement, Watt's inner voice was a narrative device that allowed her to construct and cohere different versions of her past selves. ${ }^{71}$ Through her inner dialogue, she transitioned from a young woman with limited opportunities, to an assertive individual who had a social responsibility to induce change in her area and re-enter higher education. She positioned this modern sense of self as distinct from her parent's generation, and her involvement in the MBWC was the turning point that allowed this transformation in her subjectivity.

While Watt saw the MBWC as playing a transformative role in her life story, she credited her long-term personal development to Abasindi. When asked about the impact of the MBWC and Abasindi on her life, Watt remembered, 'so the Black Women's Cooperative was a catalyst to me in terms of becoming politically involved in the black community, but my maturity came through the Abasindi Cooperative. ${ }^{72}$ The longer-term impact that Abasindi had on Watt's personal growth was demonstrated by the way in which the core values and aims of the co-operative permeated her life story. Remembering that black women's centres were intent on challenging representations of black women and the black community, it would be expected that Watt framed her life around constructing a positive identity of the black community. When discussing her involvement in setting up a supplementary school for young black children at Abasindi, she noted that, 'so we had throughout the place images, positive images, reinforcing images, you know, which the young people can begin to see that "OK. This is about us." 73 Moreover, at the end of her interview, when asked why she got involved in the oral history project, Watt said that

lots of our contribution as women, or just generally as black people in this country, is not recorded, never mind that of women. So, I just thought it was important for the organisation and the people who took part in creating it to be recognised as an important part of our history in this country. ${ }^{74}$

She thus framed her life story around working to improve the representation not simply of black women but of all black people in the historical record. She reverted to the central aims of black women's centres to be self-defining and self-determining, demonstrating the longevity of the black women's centre in the construction of her life story.

Like Watt, Elouise Edwards considered Morris as having a significant, but not transformative, impact on her life story. When Morris arrived in Manchester, Edwards already had an established reputation in Moss Side for her community politics, having begun her political life as a housing activist in the late 1960s, campaigning against insufficient council housing and inadequate play facilities for children. By the time she met Morris, Edwards had

\footnotetext{
${ }^{71}$ For coherence, see Abrams, 'Liberating the female self'.

72 Interview with Watt, LA, DYROM.

73 Ibid.

74 Ibid.
} 
established the BWMA, and was running the yearly Roots festival, centred on educating local children about their cultural heritage. Nevertheless, Edwards considered Morris's arrival as a particularly potent moment in her life: 'I don't think I, no, I never met anybody like her ... yes, one of the best days of my life was when I met Olive, yeah. ${ }^{75}$ However, there are points in Edwards's life story where her memory of Morris generated some discomfort in her sense of self. Demonstrating a similar form of reflexivity to Deane, Edwards commented, 'sometimes in my moments you know, I think about her ... [and] what would have, what would life have been like if we were still together as a group, after she died you know things, things just went pearshaped. ${ }^{76}$ Unlike Deane, whose hypothesizing allowed her to reach a sense of composure - an oral history term to mean a satisfaction with one's life story - Edwards's reflexivity was more despondent, indicating a sense of unfinished business that came about through Morris's premature death. ${ }^{77}$

Maria Noble, who was a member of Abasindi, demonstrated a similar sense of nostalgia and sense of loss regarding the direction of contemporary black activism in her interview, when she reflected, 'I kind of think where is that tradition [of activism], where has it gone? ${ }^{78}$ There are some obvious reasons for this sense of futility in these women's narratives. By 2008, Abasindi had closed its doors permanently, as many of its organizers left to pursue careers and have families. Moreover, on a national level, many black women's centres had closed. After Thatcherite policies dismantled the financial and regulatory infrastructures that allowed these groups to function, local authority grants were increasingly hard to come by in the deindustrialized north and in a post-GLC London. This lack of funding, coupled with the personal priorities of their founders, made it impossible for black women's centres to survive. These smatterings of despondency are therefore likely a product of having to recall a vivid period of activism within the context of neoliberal Britain. However, while displaying a sense of disappointment with the shape of contemporary community activism, these rose-tinted glasses allowed the women to distinguish their sense of self from successive generations. Both Noble's and Edwards's sense of nostalgia gave them a means to construct a sense of self that identified with the positive attributes of past activists, whose identities, they considered, were defined by sacrifice, solidarity, and tradition.

Indeed, Edwards's life-long history of helping people, particularly women, was the dominant theme of her life story. When she reflected on growing up in Guyana in the 1940s, she remembered that, 'I used to run the house, look after the children and everything, and of course that was when I realised you know, that there were things that women are more capable of doing. ${ }^{79}$ Later in her story, when discussing her professional transition from her role

\footnotetext{
${ }^{75}$ Interview with Edwards, LA, DYROM.

76 Ibid.

${ }^{77}$ For composure, see Penny Summerfield, 'Dis/composing the subject: intersubjectivities in oral history', in Coslett, Lury, and Summerfield, eds., Feminism and autobiography, pp. 91-106, at pp. 91-2.

${ }^{78}$ Interview with Noble, LA, DYROM.

${ }^{79}$ Interview with Edwards, LA, DYROM.
} 
as a kitchen worker to her job at Moss Side welfare advice centre, she commented:

I was working in the kitchen on the pot machine, and they would actually come to me to ask me how to do so-so-so-so-so, yeah and after a while I got a job at the advice centre, and things just took off from there, you know, I'd had enough background, and I felt strong enough you know. ${ }^{80}$

Edwards rooted her life story in her early experiences of helping people, a trait that accompanied her through her early memories of migration, and then into her eventual community role in Moss Side. While she wanted the listener to know that her job at the advice centre was the turning point in her life, her history of aiding people was in fact a recurring theme that enabled Edwards to construct a coherent life story structured around helping others.

Recalling their encounters with Olive Morris, the women of Abasindi and Manchester's black activist network constructed life stories in which being a female-centred activist was a pillar to their sense of self. Through their selfnarration, they created what Abrams has called a 'feminography', where their personal stories are rooted in their woman-centred political praxis, rather than traditional life markers, such as child-rearing or marriage. Moreover, the women filled their narratives with stories of their political engagement with other black women, displaying the fundamental role that these homosocial groupings had on the construction of black female selfhood in late twentieth-century Britain.

\section{IV}

This article has shed light on the unique but underexplored development of black women's centres and groups in the 1970s and 1980s, and in so doing has contributed to the growing body of literature on late twentieth-century black British history. It has shown how these groups catered for a generation of politically engaged black female activists who sought autonomous spaces that bolstered their sense of independence while allowing them to engage in anti-racist campaigns in the local area and the country as a whole. Moreover, by encouraging a female-centred engagement with the political and cultural output of the black diaspora, black women's centres promoted an image of black British womanhood that transcended temporal and geographical planes. This fusing of local and diasporic identities aligns with the research of Mary Chamberlain, who has shown how the life stories of migrant women of Caribbean descent are "boundless, a permeable membrane through which emotions, subjectivities, identities flow so that global identities fuse with the local'. ${ }^{81}$ In the same way, by using these centres, black British women rooted their sense of self in the shared experience of being a woman in the global black diaspora. Moreover, while black women's groups

\footnotetext{
80 Ibid.

${ }^{81}$ Chamberlain, 'Global self', p. 164.
} 
waned from the 1980s, this article has demonstrated that their physical disappearance did not negate their lasting impact on black women's lives. While each of the women who contributed to the DYROM oral history project had a unique life story, all of them saw their engagement with black women's centres and groups as having a transformative impact on their life course. Thus, despite these centres being almost invisible in the literature on black Britain, their centrality to the sense of self of many black women indicates that their significance is far greater than has previously been assumed.

Finally, this article has shifted the focus onwards from the narratives of migration and settlement that have shaped black British history. By centring the importance of selfhood to black female activism, it has highlighted the importance of the 'personal' in Britain's anti-racism movement, while also setting crucial groundwork for future research into black women's lives outside activism. Moreover, viewing black women's activism from a regional perspective, the article has highlighted the varying forms that black women's activism took. While organizations such as OWAAD campaigned against national issues, looking at the formation of black female activism in Manchester - and, indeed, some of the tensions within the network - emphasizes the primacy of localism in these networks. Britain's black population in the 1970s and 1980s was not a homogenous and unchanging group, but was made up of distinctive and complex communities that were shaped by their immediate environment. Examining Manchester's activism highlights the centrality of the 'local' to Britain's anti-racist movements, and, indeed, to black British history.

Acknowledgements. Many thanks to the anonymous readers for their suggestions. The author would also like to thank Kerry Pimblott, Jack Webb, Frances Houghton, Laure Humbert, Eloise Moss, Georgia Vesma, and Roseanna Webster for their extensive comments.

Cite this article: White J (2022). Black Women's Groups, Life Narratives, and the Construction of the Self in Late Twentieth-Century Britain. The Historical Journal 65, 797-817. https://doi.org/ $10.1017 /$ S0018246X21000492 